\title{
Design Proposal for Riverbanks Settlement Resilience through Respect to Site Approach
}

\author{
Avinda T. A. Vielandy ${ }^{1}$, FX Teddy Badai Samodra ${ }^{1}$
}

\begin{abstract}
In urban environment, the growing number of population increases the high level of housing needs, while publicly provided housing is sufficient. This is the main cause of the emergence of slums. This design research aims to upgrade the riverbank slum into a green settlement with improved housing quality by implementing six principles of Green Architecture into design. Field measurement and interview were conducted to obtain data for simulation using Ecotect Analysis and ANSYS Fluent software. The result highlighted that resilience design conducted through respect to site as on of the green architecture principles has the capability to achieve compatibility between user and environment.
\end{abstract}

Keywords - Green architecture, resilience design, riverbank settlement, slum area

\section{INTRODUCTION}

Unsustainable urbanization will cause damage to urban areas. Some countries could not keep up with the rapid speed and the large scale of urbanization. Rapid urbanization has created problems of land and housing scarcity, and as these scarcities increase and housing prices rise, economic constraints force the poor to inhabit land that no one else wants [1]. The governments tend to exclude the urban poor by not recognizing their rights and not incorporating them into urban planning. These are the main causes of the growing number of urban residents living in informal settlements, or should we call, the emergence of slums. Because slums are the only type of settlement that affordable and accessible to the urban poor, where competitions of land and profits do not support them to afford decent housing. Slums are often formed in city waste disposal sites, railway tracks, riverbanks; and private unoccupied land ([2].

In Jakarta, riverbanks slums can be found along the side of Ciliwung River. These slums and their inhabitants will have a significant contribution to environmental degradation of Jakarta. It is because of rivers and their banks are vulnerable to activities and process that cause pollution and degradation of the ecosystem [3]. The most common solution proposed by the government is the top down planning [4]. This solution consists of two steps: forced eviction and resettlement program. The slum dwellers are evicted in an inhumane way and then they are resettled into a social housing provided with unfavorable terms and conditions. Obviously, this solution is not viable. This solution will not solve the problem, it will only cause more problems such as economic and social disruption [5]. Therefore, a more viable solution is needed.

\footnotetext{
${ }^{1}$ Avinda T.A. Vielandy and FX Teddy Badai Samodra are from Department of Architecture, Faculty of Architecture, Design and Planning, Institut Teknologi Sepuluh Nopember (ITS), Kampus ITS Sukolilo, Surabaya 60111, Indonesia. E-mail: avinda13@mhs.arch.its.ac.id; fxteddybs@arch.its.ac.id.
}

To respond the issues explained above, this design research aims to upgrade the riverbank slum into a green settlement resilience with improved housing and proper facility that will increase the livelihood of the inhabitants with minimal effect to the environment; proposing a better solution than the one offered by the government. Green Settlement is a settlement that minimizes the use of energy and resources without neglecting thermal and visual comfort of the user with minimal negative aspects towards the environment (CO2 emission, flood, water contamination, soil, and air) [6].

The research site is located in RW 12 of Bukit Duri, Tebet, South Jakarta; the site shape is lengthwise following the form of the river. The site is sloped at 6,25deg and is prone to erosion since there are no vegetation that protects the banks. According to field measurement and climatic data, the climate condition of the site is rather awful; the temperature and the relative humidity is high (31deg and 69\%), the daylight level is low, and the rainfall is high. The existing settlement consists of 4 neighborhoods; RT 001, RT 002, RT 003, and RT 003. There are approximately 198 families inhabiting the settlement. Data obtained from the interview states that there are three types of occupations of the inhabitants: wood worker, informal trader, and casual laborer.

The existing settlement is in a very poor condition, the area is awfully dense; there's almost no space in between the houses, the alleys are terribly narrow (less than $1 \mathrm{~m}$ ), most of the buildings are in an improper condition; they do not meet the basic requirements of dwelling, there is no public facility provided other than the limited capacity prayer hall, and the settlement is lacking in open space, the residents usually hang out or gather around in front of their houses or in the narrow alleys. From the survey that was held in September (2016), there was a peculiar phenomenon found: most of the houses have two stories; the upper level is used as a "safe space" when flood occurs.

\section{DESIGN METHOD}

\section{Green Architecture}

By implementing Green Architecture into the design, the scheme formed will have minimal intervention to the environment and utilization of riverbanks can be optimized. Green Architecture is concerned about energy conservation, user comfort, and environment preservation. Green architecture aims to achieve compatibility between user and environment by combining three main factors: Efficient use of resources and materials, optimal handling of prevailing climatic, geographic, and social conditions, and providing the present human needs while preserving the needs of future generation [7]. Green architecture is going to play a major role in the approaching process of this design research. Six principles of Green architecture are 
implemented to the design: Conserving energy (E), Working with climate (C), Minimizing new resources (R), Respect for user (U), Respect for site (S), and Holism (H). These principles are based on Green Architecture by Vale \& Vale [8]. The design will be divided into two scopes to ease the design process; site and building. These two contexts will be generated into a few points of concepts and each points are based on the six principles of Green Architecture. All concepts concerning in thermal is analyzed by using Ecotect Analysis Software and ANSYS Fluent software.

The research roadmap below (Figure 1) shows the scope, context, and the specification of the research. It states that this research is focused on energy, ecology, thermal, lighting, and ventilation on settlement, building, interior, and material scopes.

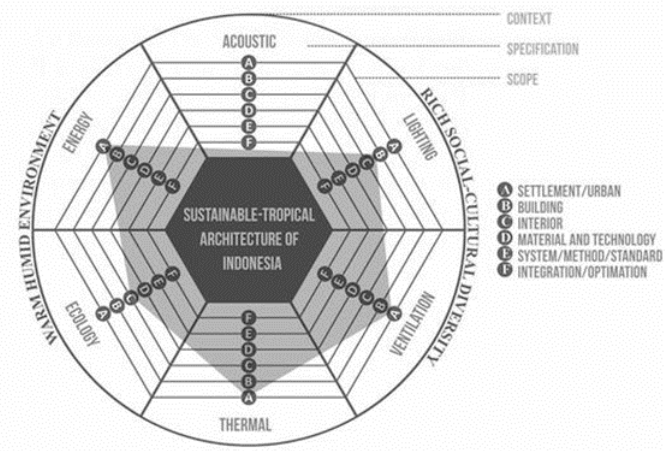

Figure 1. Research roadmap

\section{RESULTS AND DISCUSSION}

Integrated green principle as proposed on site design context is shown in Table 1.

TABLE 1.

DESIGN CONCEPTS OF THE SITE CONTEXT

\begin{tabular}{|c|c|c|c|c|c|c|c|c|}
\hline \multicolumn{2}{|c|}{ SCOPE } & CONCEPT & $\mathrm{E}$ & $\mathrm{C}$ & $\mathrm{R}$ & $\mathrm{U}$ & $\mathrm{S}$ & $\mathrm{H}$ \\
\hline \multirow[t]{14}{*}{$\begin{array}{l}\text { Site } \\
\text { (S) }\end{array}$} & \multirow{5}{*}{$\begin{array}{l}\text { S1 } \\
\text { River- } \\
\text { bank } \\
\text { area }\end{array}$} & $\begin{array}{l}\text { S.1.1 Flood Risk } \\
\text { Zoning }\end{array}$ & & & & 0 & 0 & 0 \\
\hline & & $\begin{array}{l}\text { S.1.2. Erosion } \\
\text { Protection Strategy }\end{array}$ & & & & 0 & 0 & 0 \\
\hline & & S.1.3 Micro hydro & 0 & & o & & o & 0 \\
\hline & & $\begin{array}{l}\text { S.1.4 Fire Protection } \\
\text { strategy by utilizing } \\
\text { river water }\end{array}$ & & & 0 & 0 & 0 & 0 \\
\hline & & S.1.5 Elevated Pathway & & & & 0 & 0 & \\
\hline & \multirow{4}{*}{$\begin{array}{l}\text { S2 } \\
\text { Slum } \\
\text { Area }\end{array}$} & $\begin{array}{l}\text { S.2.1 Green Open } \\
\text { Space }\end{array}$ & & 0 & & 0 & 0 & 0 \\
\hline & & $\begin{array}{l}\text { S.2.2 Housing } \\
\text { arrangement }\end{array}$ & & 0 & & 0 & 0 & o \\
\hline & & S.2.3 Public Facility & & & & 0 & & 0 \\
\hline & & $\begin{array}{l}\text { S.2.4 Communal Utility } \\
\text { System }\end{array}$ & & & 0 & 0 & & o \\
\hline & \multirow{5}{*}{$\begin{array}{l}\text { S3 } \\
\text { Cli- } \\
\text { mate } \\
\text { Con- } \\
\text { dition }\end{array}$} & S.3.1 Microclimate & & 0 & & 0 & & 0 \\
\hline & & S.3.2 Rain Garden & & 0 & & 0 & 0 & 0 \\
\hline & & $\begin{array}{l}\text { S.3.3 Permeable } \\
\text { Pavement }\end{array}$ & & 0 & & & 0 & 0 \\
\hline & & S.3.4 Swale Drainage & & 0 & & & 0 & 0 \\
\hline & & $\begin{array}{l}\text { S.3.5 Vegetation } \\
\text { Pavement }\end{array}$ & & 0 & & 0 & 0 & 0 \\
\hline
\end{tabular}

Respect to site has been considered as the major priority on this research and it is a very crucial principle in order to restore and to repair the flood riverbank condition, resilient method should be included in the designing process. Therefore, the site needs to be designed properly (S.1). The site is divided into three zones based on its risk level of flood (S.1.1). Furthermore, to prevent erosion that often occurs in riverbank area, vegetation will play an important role in soil retention and stabilization (S.1.2). River utilization can be achieved by designing a micro hydro power plant (S.1.3) in the settlement, by using river current as the source that will generate electricity. The river is also used in the fire protection strategy (S.1.4). (S.1.5) Elevated pathway is also provided in the settlement.

To deal with slum area problems (S.2), green open space (S.2.1) is immensely needed. The existing settlement has an awful housing arrangement; the proposed design has a better housing arrangement (S.2.2) using the combination of loop pattern and cluster plan, this housing arrangement creates more space in between the houses. In the existing settlement, there are no public facility provided, in the proposed design Community Hall, Community Health Centre, park, and prayer halls are provided to facilitate the inhabitants (S.2.3).

The climate condition of the existing settlement is found to be uncomfortable for the resident (S.3), consequently the proposed settlement has to be designed to give a comfortable climatic condition. First, to decrease the urban heat island (UHI), the landscape needs to be designed properly to endorse better microclimate (S.3.1). To come up with the high level of rainfall, rain gardens (S.3.2) need to be designed in the settlement. Permeable pavement (S.3.3) will be used in the settlement to allow greater runoff absorption; the permeable pavement will support the rain gardens in dealing with the high rainfall. Implementing the concept of Swale drainage (S.3.4) on the settlement will also help with the high level of rainfall. The vegetation arrangement (S.3.5) of the site has an important role in providing user thermal comfort through promoting wind acceleration. This pathway height is approximately $4 \mathrm{~m}$. When the dwellings float, the users can access the elevated pathway by the compact foldable bridge that is provided in the terrace of the dwellings.

\section{S.1 Riverbank area}

The settlement is located on the riverbank of Ciliwung River. It is a $119 \mathrm{~km}$ long river that flows through the special region of Jakarta. The river is identified as the critical factor of Jakarta annual floods. But the river also plays an important role in the inhabitants' life, since people tend to look for a place to live that is near a water body to fulfill their daily needs.

\section{S.1.1 Flood Risk Zone}

The site is divided into three flood risk zones; highrisk zone, moderate zone, and safe zone. The zoning is determined from the altitude of the zone and the average floodwater height on each zone. The high-risk zone is the zone near the river, this zone has the lowest altitude compared to the other zones, this zone is affected badly when flood comes, the buildings in this zone are badly submerged by the flood water. Moderate zone is located in the middle part of the site, the buildings in this zone is submerged too, but not as bad as the buildings in the high-risk zone. And safe zone is the nearest from the main street, it has the highest altitude than the other zones, among all the other zones, this zone is the safest zone. The zoning is illustrated in Figure 2. 
The zoning is created to determine the suitable structure of the building on each zone. The amphibious structure is used on the high-risk zone, the stilts structure is used on the moderate zone, while the conventional ground structure with damp proofing is used on the safe zone (Figure 3).

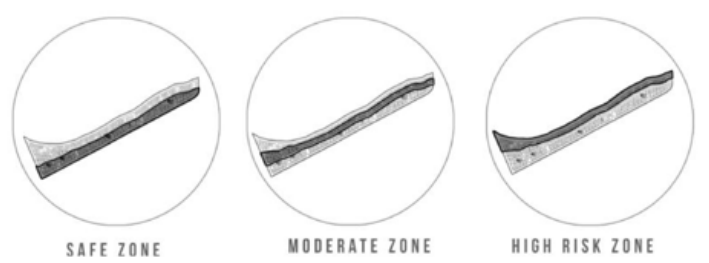

Figure 2. Flood risk zones

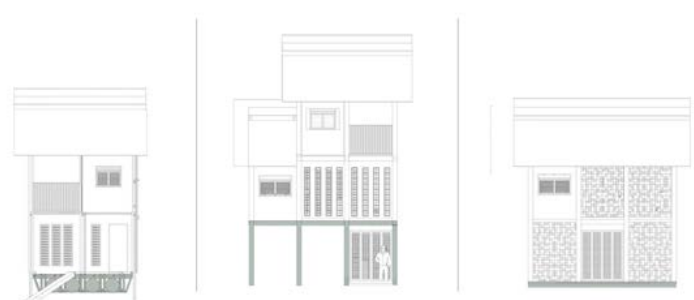

Figure 3. Dwellings structure based on the flood risk zone

The amphibious structure has the ability to float when flood occurs. The structure allows the house to remain above the water level. Thus, the inside of the house (the user, the furniture, etc) is safe from the flood. The structure has four anchoring steel piles that help the house to shift up and down and prevent it to move horizontally. It has float that is made out of empty oil tanks and a bamboo frame. Most of the component of the structure is made out of bamboo, except for the anchoring steel piles. The detail of the structure is illustrated further in Figure 4. Bamboo is chosen because it is categorized as lightweight material, is available locally and regionally, and grows rapidly. In other word, this material is sustainable and suitable for dwellings in the high-risk zone.

The dwellings in moderate zone are raised on $2.3 \mathrm{~m}$ stilts, the height of the stilts keep the house safe from the water when flood comes. The height of the stilts is determined from the average flood height and the altitude of the moderate zone. The stilts structure consists of stilts made out of $150 \times 300 \mathrm{~cm}$ steel columns layered with $2 \mathrm{~mm}$ thick of mineral fiber. The mineral fiber layer will protect the steel from water and it will enhance the heat endurance of the steel (fire protection). The area below the dwellings can be functioned as social space and when flood comes it also acts as retention area. Putting the houses on stilts structure also increases absorption area of the site, giving a better chance at ground water replenishment.

The flood in safe zone is considered to be not as critical as the other two areas. Thus, the dwellings in this area only use the conventional ground structure, the only special feature in this model is the damp proofing. Damp proofing in construction is a type of moisture control applied to building walls and floors to prevent moisture from passing into the interior spaces. Damp problems are among the most frequent problems encountered in houses. Especially those located near the water body. A damp-proof course (DPC) is a barrier through the structure by capillary action such as through a phenomenon known as rising damp. Rising damp is the effect of water rising from the ground into the house. The damp proof course may be horizontal or vertical. A DPC layer is usually laid below masonry walls, regardless if the wall is a load bearing wall or a partition wall. From the explanation above, it can be said that 'respect for user' is also highly considered in this point.

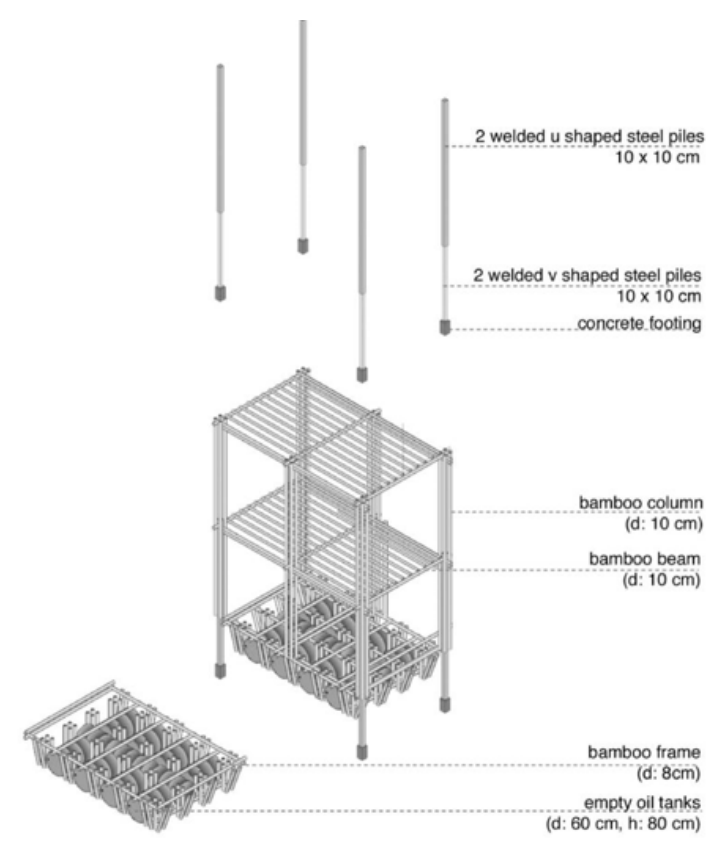

Figure 4. Bamboo structure detail

\section{S.1.2 Erosion Prevention Plants}

There will be three types of plants that will be planted on the site to help prevent erosion: (a). Tree as hillside stabilization: Gigantochloa apus; (b). Shrub as soil retention and limited hillside stabilization: Crotalaria anagyroldes; and (c). Groundcover as surface soil retention: Centrosema pubescens Benth 'Respect for user' is also implemented in this point, considering the safety of the users is a crucial thing.

\section{S.1.3 Micro hydro power plant}

Micro hydro is a type of hydroelectric power that typically produces from $5 \mathrm{~kW}$ to $100 \mathrm{~kW}$ of electricity using the natural flow of water. The electricity generated by the micro hydro power plant from the river current will be used for the public facility and other community needs. Micro hydro power plants are made up of a few components; intake weir (1), settling tank (2), penstock (3), water return (4), power house (6), and transformator (5). The component of the micro hydro power plant is illustrated in Figure 5. Other than respecting the site, this point also includes 'conserving energy' (using alternative energy source) and 'minimizing new resources' (river water utilization).

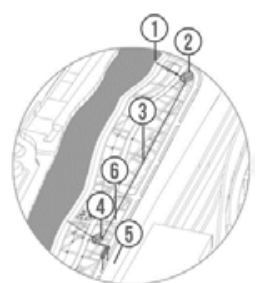

Figure 5. Micro hydro power plants 


\section{S.1.4 Fire Protection Strategy}

The river water will be the water source in fire mitigation. When river water rises, it will go into the underground water tank and stored as the water source. The underground tanks are connected to outdoor hydrants that are planted along the riverbanks. The fire protection system is explained in Figure 5. This point also works for 'respect for user' because it guarantees the users safety and 'minimizing new resources' since it's utilizing the river water.

\section{S.1.5 Elevated Pathway}

Elevated pathway is built in the high-risk zone. The elevated pathway allows the users who live in the highrisk zone (the casual laborers) to access the main road when their dwellings are still flooded with water. The users can access the elevated pathway by using the mini foldable bridge that is provided in their dwellings (only applies for casual laborers' dwelling) (Figure 6). The elevated pathway is made out of steel columns, perforated metal panel, and bamboo panel. At the end of each pathway, stairs to access the main road is provided. This pathway height is approximately $4 \mathrm{~m}$. When the dwellings are floating, the users can access the elevated pathway by the mini foldable bridge that is provided in the dwellings (respect for user).

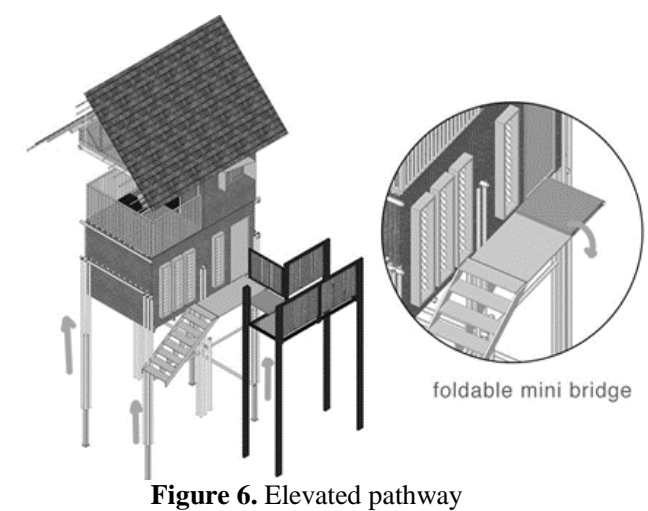

\section{S.2 Slum area}

The settlement is categorized as a slum resident. The area is dense and the buildings are in bad conditions. Despite its small area, it is inhabited by 198 families, creating a dense and uncomfortable environment.

\section{S.2.1 Green Open Space}

Green open space is an area of grass, trees, or other vegetation set apart for recreational or aesthetic purposes in an otherwise urban environment. Green open space is a crucial element of a settlement. Its presence will enhance the beauty and the environmental quality (working with climate) of the settlement. It will also act as an interaction space between the users (respect for user)

\section{S.2.2 Housing Arrangement}

The housing arrangement is designed to create more open space in between the houses. In order to achieve that, the housing is divided into a few clusters forming a loop pattern. Cluster pattern will leave about $50 \%$ of the site to become open space, will loop pattern will guarantee the ventilation quality of the settlement. The space formed in between the houses can be utilized as the sub-communal space, it will act as the social space (respect for user) in the sub-cluster scale.

\section{S.2.3 Public Facility}

The community hall, the community health center, and the park are located in the middle of the settlement to increase the accessibility of the facility (respect for user). While the prayer halls are provided in each neighborhoods.

\section{S.3 Climate Condition}

The site is located in a hot humid tropical area. Data obtained from field measurement states that 31 degrees Celsius and $70 \%$ are the average temperature and the average relative humidity.

\section{S.3.1 Microclimate}

An urban heat island (UHI) is an urban area or metropolitan area that is significantly warmer than its surrounding other rural areas due to human activities. To create a comfortable microclimate (respect for user and working with climate), a strategy to reduce urban heat island (UHI) is needed. The proposed settlement needs to have a balanced composition between building and landscape (tree and turf). The ideal composition is $40 \%$ building and 60\% landscape (tree and turf).

\section{S.3.1 Rain Gardens}

Rain gardens are man-made, shallow depressions that are planted with deep-rooted plants and grasses, preferable native or local species. Rain gardens will captive storm water runoff water from roofs, walkways, driveways, pavement, compacted lawn areas and any other surfaces (Figure 7).

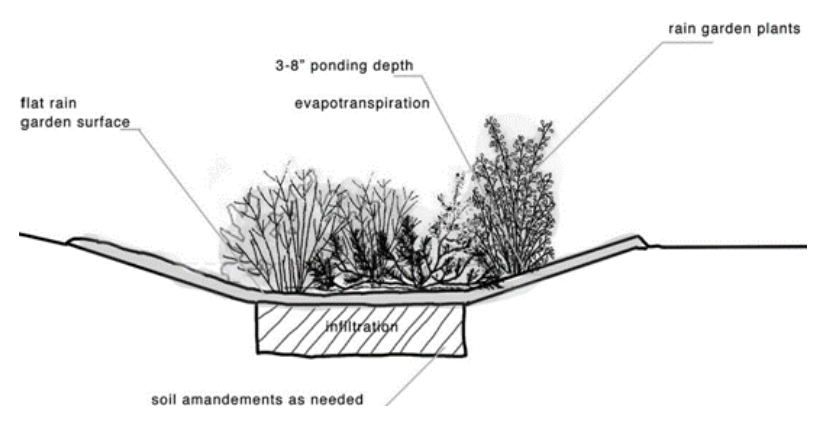

Figure 7. Rain garden

Although the main function of rain gardens is to retain and treat storm water runoff, rain gardens will also improve the landscape, replenish ground water supply, clean runoff from pollutant and lessen the runoff. The rain gardens will be planted with native species; those plants are:

a. Wedelia (Sphagneticola trilobata)

Wedelia forms a dense ground cover that crowds out weeds, but can also crowd out other plants so must be regularly pruned. It grows well in shade and in poor soil, and is useful for erosion control.

b. Lemon Grass (Cymbopogon)

Lemon Grass oil is used as pesticide and a preservative. Research shows that lemon grass oil has anti-fungal properties. Despite its ability to repel insects, its oil is used as a "lure" to attract honey bees.

c. Elephant Ear (Alocasia sanderiana)

Alocasia species are native to southeastern Asia and the Indian subcontinent and widely cultivated as ornamentals. They are herbaceous perennial plants with a large corm on or just below the ground surface. The leaves are large to very large, 20-150 cm long, with an 
agitate shape. This point is truly affiliated with 'working with climate'.

\section{S.3.2 Permeable Pavement}

Permeable paving is a range of sustainable materials and techniques for permeable pavements with a base and sub-base that allow the movement of storm water through the surface. In addition to reducing runoff, this effectively traps suspended solids and filter pollutants from the water (Figure 8). Permeable pavement, unlike the conventional one, permits water to drain through it. One of the permeable paving used in the settlement is grass block. Grass block also allows greenery to grow through it to enhance the filtration quality.

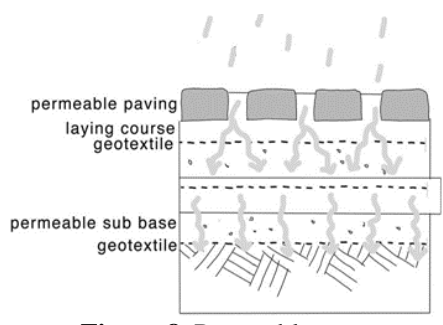

Figure 8. Permeable pavement

\section{S.3.3 Swales}

Swales are shallow, broad, and vegetated channels designed to store and/ or convey runoff and remove pollutants. They may be used as conveyance structures to pass the runoff to the next stage of the treatment train and can be designed to promote infiltration where soil and groundwater conditions allow (Figure 9). They will also reduce runoff rates and volumes. Swales in this settlement will decrease the level of pollution that goes straight to the river, because Swale drainage absorbs, treats, and infiltrates runoff and wastewater before flowing to the river. Swales are composed by a few components; vegetation (Centrasema pubescens Benth), permeable soil, pebbles, and PVC pipe for water distribution.

\section{S.3.4 Vegetation Arrangement}

The ventilation in the existing settlement is very poor, field measurement says the wind speed in this settlement is $0-0,4 \mathrm{~m} / \mathrm{s}$, this is because of the building density and the absence of vegetation. In the designed settlement, vegetation (trees) is arranged in certain pattern and following a certain axis to allow wind penetration into the settlement. Two models of vegetation arrangement (model a and model b) were simulated by ANSYS Fluent and Ecotect Analysis software to determine which vegetation arrangement could help accelerate the wind speed better. The simulation shows that model $b$ has the better result than model a: model $b$ accelerates wind better that leads to the promotion of better thermal comfort (respect for user) (Figure 10).

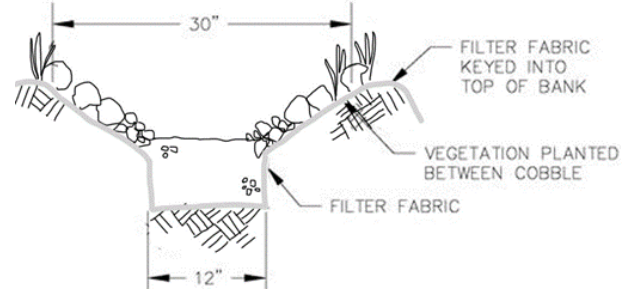

Figure 9. Swale drainage illustration
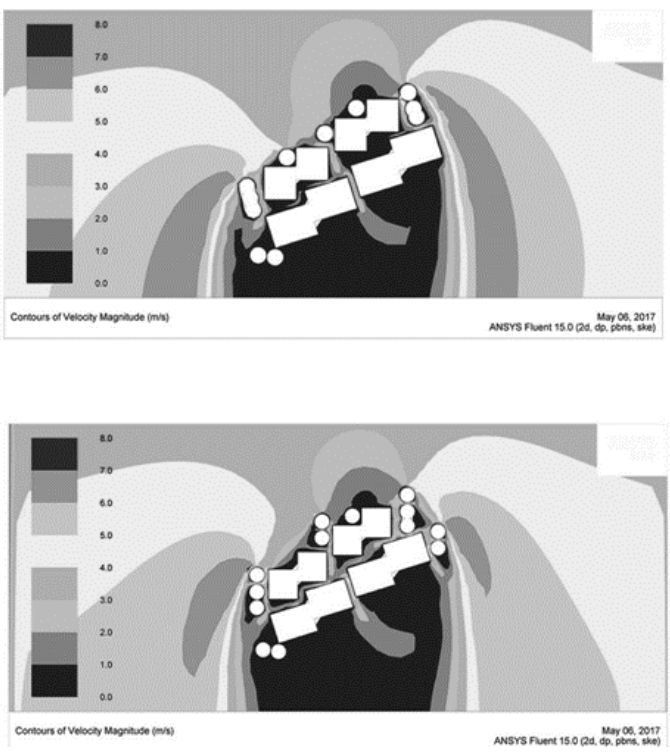

Figure 10. Vegetation arrangement simulation

\section{CONCLUSION}

The scheme formed in minimal intervention to the environment and utilization of riverbanks can be optimized. In line with Hussein [7], this proposed design has capability to achieve compatibility between user and environment by combining three main factors: Efficient use of resources and materials, optimal handling of prevailing climatic, geographic, and social conditions, and providing the present human needs while preserving the needs of future generation. The objective of the design research, that is to upgrade the riverbank slum into a riverbank green settlement can be achieved by implementing six principles of Green architecture, with 'respect for site' as the main focus of the discourse.

\section{ACKNOWLEDGMENT}

This research is publication of Final Project Report, Department of Architecture-ITS Surabaya supported by Penelitian Doktor Baru No. 881/PKS/ITS/2017, Dana Non PNBP ITS 2017. The authors gratefully acknowledge this financial and technical supports.

\section{REFERENCES}

[1] A. E. Pravitasari, "Study on Impact of Urbanization and Rapid Urban Expansion in Java and Jabodetabek Megacity, Indonesia,” Kyoto University, 2015.

[2] L. Winayanti and H. C. Lang, "Provision of urban services in an informal settlement: a case study of Kampung Penas Tanggul, Jakarta,” Habitat Int., vol. 28, no. 1, pp. 41-65, Mar. 2004.

[3] C. Z. Yu and E. E. Sajor, "Urban River Rehabilitation: A Case Study in Marikina City, Philippines,” 2008.

[4] M. Majale, "Employment creation through participatory urban planning and slum upgrading: The case of Kitale, Kenya," Habitat Int., vol. 32, no. 2, pp. 270-282, Jun. 2008.

[5] T. Adi Purnomo and I. Hardjanto, "Slum Resettlement Along Brantas Riverbanks Case Study at Malang City, East Java,” J$P A L$, vol. 4, no. 2, pp. 20-28, 2013.

[6] T. H. Karyono, Green Architecture: Pengantar Pemahaman Arsitektur Hijau di Indonesia: Tri Harso Karyono - Belbuk.com. Jakarta: Rajawali Pers, 2010.

[7] W. Hussein, "Slums Issues in Egypt: An Approach to the Application of Green Building Concepts,” J. Econ. Sustain. Dev., vol. 6, no. 5, pp. 225-244, 2015.

[8] B. Vale and R. Vale, Green architecture: design for a sustainable future. Thames and Hudson, 1991. 